Review Article

www.ijrap.net

\title{
AYUR INFORMATICS: NEED OF THE HOUR
}

Sushant Sud $^{1 *}$, Khyati S. Sud ${ }^{2}$

${ }^{1}$ Dept of Agad Tantra, International Course for Ayurvedic Studies, Shree Gulab Kunwerba Ayurved College, Gujarat Ayurved University, Jamnagar, Gujarat, India

${ }^{2}$ Dept of Kaya Chikitsa, International Course for Ayurvedic Studies, Shree Gulab Kunwerba Ayurved College, Gujarat Ayurved University, Jamnagar, Gujarat, India

Received on: 05/12/12 Revised on: 17/01/13 Accepted on: 11/02/13

\author{
*Corresponding author \\ E-mail: drsushantsud@gmail.com \\ DOI: $10.7897 / 2277-4343.04242$ \\ Published by Moksha Publishing House. Website www.mokshaph.com \\ All rights reserved.
}

\section{ABSTRACT}

Ayurved, the traditional Indian medicines remains the most ancient yet living traditions. Information technology is currently taking center stage and has transformed the entire world into a global market. Globalization and vast spreading competition all around have accelerated the need for knowledge and intensive work performance in all the sectors of economy.

The globalization, product patency, intellectual property rights issues and most important bio-piracy are becoming major challenges in the traditional indigenous medical (TIM) system like Ayurved. Efforts to monitor and regulate Ayurvedic traditional medicines are underway. Existing Information and Communication Technology implementations are mostly and to be specific largely top-down in their flow of information i.e. from experts to target groups.

Ayurved needs to be restructured globally to meet the rising demands of a cyber mobile society with the application of information and communication technology. This paper discusses the impact of IT and the advances in information and communication technologies (ICTs) in this scientific age .Therefore, Ayurved needs Ayur-informatics to keep pace with this modern world

Keywords: Ayurved, Globalization, ICT, Ayur-informatics

\section{INTRODUCTION}

Ayurved, the traditional Indian medicines remains the most ancient yet living traditions. Ayurved an ancient system of health and medicine practiced in India unfortunately, known more for its commercial rejuvenating SPAS than as a 'Science'. Denial of the label of 'science' in western countries creates an obvious bias Ayurved is seen as 'lesser' than the western medical system.

The present practice of Ayurved emphasizes on traditional way. The globalisation, patent, intellectual property rights issues and bio piracy are becoming major challenges in the indigenous traditional medical system like Ayurved. In order to promote Ayurved as a global medicine and equip it to meet the global healthcare needs of the 21st century, there is an urgent need to modernise the ancient system in pace with the development of science and technology.

The information technology revolution is being described as the most important development in the history of humankind since the industrial revolution ${ }^{1}$. Information technology is currently taking centre stage and transformed the whole world into a global village with a global economy, which is increasingly dependent on the creative management and distribution of information. It has enormous advantages in rapid and easy delivery of information around the world. The paper discusses the impact of information technology and role of libraries in the age of knowledge and information societies. It also highlights the problems faced by the Library and Information Service (LIS) sector in India and achievements over the years using modern information technologies ${ }^{2}$.

\section{METHODS}

The World Bank has used metaphor "knowledge is development". Lack of knowledge is largely responsible for under development ${ }^{3}$.

- Emergence of Information and Knowledge Societies.

- Impact of Globalization and Emerging Information Communication Technologies.

- Using ICT to place Indigenous Knowledge Systems at the heart of Education for sustainable development.

- Role of Information Technology in Ayurved in this Digital Age.

- The Internet: It's Role in Medicine and Healthcare.

The information society has passed through four transformational stages of development, the most radical stage starting at end of the 20th century. This stage has brought a never-ending revolution, particularly with the introduction of information and communication technologies. During this period, there have been unprecedented developments, profoundly affecting the social structure - the decline of manufacturing sector as compared to the prospering information-rich service sector is one example of such developments.

India is moving fast towards becoming an information society as the Government of India is paying due attention to the use of information technology (IT). The Prime Minister of India constituted a National Task Force on IT and Software Development in May 1998 with the purpose of formulating a long-term National IT Policy to transform India into an IT hub mainly in software sector. Exchange of knowledge has always been the most important objectives of libraries. Various systems have been developed to share and exchange the records of 
human knowledge. In the modern knowledge society libraries have a new role and there are various types of library models. These are as follows:

- Traditional library as a memory institution

- Library as a learning and research centre

- Library as a cultural and communication centre

- Electronic library

- Digital library

The ongoing process of globalization has influenced all the sectors of economy including the medical sector. Globalization has offered enormous opportunities but also threats to communities that are not adequately prepared to face its challenges. It has created turbulence, uncertainty, competitiveness, need for adaptation to change and timely adoption and absorption of technologies. "As the world is globalizing, a global knowledge and information society is emerging, spanning all regions. Knowledge and information have become significant factors for production of goods and services.

The information technology revolution is being described as the most important development in the history of humankind since the industrial revolution. Characterised as 'The Third Wave' by Alvin Toffler, in his book of the same title, it has the potential to change the ways of man and society beyond the wildest of imaginations. The computer, invented initially to process information, slowly grew into a storehouse of information. It then became sophisticated and ever more powerful and got hooked to others of its kind to form a formidable network. This network further acquired the capability of distributing electronically processed information to all and sundry, overcoming every conceivable form of barriers, including geographical and political. Today, it is a global collaborative medium and a rich resource of information of all kinds - science, technology, research, education, and commerce. Through a host of emerging tools and protocols, it enables person- to- person, computer-to-computer, or person- to- computer communication ${ }^{4}$.

\section{The present situation}

Ayurved treatment is individual based and drug production is a time consuming process. The Ayurved medicines cannot be prepared in bulk quantity in a very short time and supplied immediately as in the case of Allopathic medicine. Another important point in Ayurved medicine is its way of treatment. Many practitioners still resort to the traditional ways to diagnose the disease. The regulations of this sector are quite old and totally insufficient to support the industry in modern developments. This system, which has proven in India for hundreds of years, has kindled the interest of the entire world and they look at it as an alternative holistic global health care system. But Ayurved is not yet equipped to meet the challenges of the cyber society. So considering all these facts, Ayurved needs a restructuring in the global context to meet the rising demands of a cyber society ${ }^{5}$.

\section{Internet: An information tool}

With continuing advances in information and communication technology, the applications of computers in medicine have increased rapidly, and have the potential to revolutionise healthcare and the Internet, with its powerful penetration and scalability, has become an increasingly popular medical information resource ${ }^{6}$. Internet is a powerful tool of information in different parts of world ${ }^{7}$. Statistics of internet users are cited in Table 1.

\section{Useful and Handy Source of Knowledge with continuing advances in IT sector}

- Applications of computers in medicine have increased rapidly.

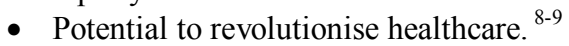

Some of the major Ayurved related Indian web sites are listed in Table 2 and 3.

\section{Computer based Ayurved practice}

The potential for Information technology to help medical practitioners to perform the complex information management tasks of patient care has long been recognised. Many promising systems that incorporate advanced information technology have been developed for clinical use, with regular improvements in availability, speed, and ease to use. The computerized Ayurved studies have identified several important factors that affect the current and future role of computers and information technology in Ayurved treatment. The major computer based Ayurved packages are. ${ }^{10}$

\section{Body Tune-Computerized Ayurvedic Medicare (CAM)}

Body Tune, developed in 1983 is an interactive Computerized Ayurvedic Medicare software concept contributing to Ayurveda in three basic interrelated ways. It detects and communicates data about the physical conditions. It interprets that data, and actively helps in assessment and accurate diagnosis. It helps to organize the diagnostic method in a classical way envisaged by Indian Sages of Ayurveda.

\section{Prakes}

An expert system for the estimation of Prakrti developed by CIRA (Centre for Informatics Research Advancement, Kerala) in 1987.

\section{Prakrti}

This is an expert system designed and developed by Chaitanya Consultancy, Pune in 1989. It gives users Prakrti, health advice regarding diet, instructions about daily activities, likely illness and measures for its prevention.

\section{Madhava}

Centre for Development of Advanced Computing, Pune. Based on Ayurvedic System of Medicine to diagnose a wide variety of diseases in 1991.

\section{Rasex}

This package was developed by Government Ayurvda College, Trivandrum, CIRA and ER and DC, Trivandrum in 1992. In this package an attempt has been made to correlate the pharmacological properties with therapeutic properties i.e. help of computer. 
Table 1: World Internet Usage and Population Statistics June 30, 2012

\begin{tabular}{|c|c|c|c|c|c|c|}
\hline \multicolumn{7}{|c|}{$\begin{array}{c}\text { World Internet Usage and Population Statistics } \\
\text { June 30, } 2012\end{array}$} \\
\hline World Regions & $\begin{array}{l}\text { Population } \\
\text { (2012 Est.) }\end{array}$ & $\begin{array}{c}\text { Internet Users } \\
\text { Dec. 31, 2000 }\end{array}$ & $\begin{array}{c}\text { Internet Users } \\
\text { Latest Data }\end{array}$ & $\begin{array}{c}\text { Penetration } \\
\text { (\% Population) }\end{array}$ & $\begin{array}{c}\text { Growth } \\
2000-2012\end{array}$ & $\begin{array}{l}\text { Users \% } \\
\text { of Table }\end{array}$ \\
\hline Africa & $1,073,380,925$ & $4,514,400$ & $167,335,676$ & $15.6 \%$ & $3,606.7 \%$ & $7.0 \%$ \\
\hline Asia & $3,922,066,987$ & $114,304,000$ & $1,076,681,059$ & $27.5 \%$ & $841.9 \%$ & $44.8 \%$ \\
\hline Europe & $820,918,446$ & $105,096,093$ & $518,512,109$ & $63.2 \%$ & $393.4 \%$ & $21.5 \%$ \\
\hline Middle East & $223,608,203$ & $3,284,800$ & $90,000,455$ & $40.2 \%$ & $2,639.9 \%$ & $3.7 \%$ \\
\hline North America & $348,280,154$ & $108,096,800$ & $273,785,413$ & $78.6 \%$ & $153.3 \%$ & $11.4 \%$ \\
\hline Latin America / Caribbean & $593,688,638$ & $18,068,919$ & $254,915,745$ & $42.9 \%$ & $1,310.8 \%$ & $10.6 \%$ \\
\hline Oceania / Australia & $35,903,569$ & $7,620,480$ & $24,287,919$ & $67.6 \%$ & $218.7 \%$ & $1.0 \%$ \\
\hline WORLD TOTAL & $7,017,846,922$ & $360,985,492$ & $2,405,518,376$ & $34.3 \%$ & $566.4 \%$ & $100.0 \%$ \\
\hline
\end{tabular}

Table 2: Names of some of the major Ayurved-related Indian web sites

\begin{tabular}{|c|c|c|}
\hline Name of the Website & Name of the Website & Name of the Website \\
\hline http://www.ayurvedic.org & http://www.ancientayurveda.com & http://health.indiamart.com/alternativemedicine \\
\hline http://www.ayurvedwebline.com & http://www.ayurveda-foryou.com & http://www.indiandoctors.com \\
\hline http://www.ayurvarta.com/eng & http://www.ayurvedic-medicines.com & http://www.indianhealthzone.com \\
\hline http://www.baidyanath.com & http://www.herbalhealerz.com & http://www.indiayogi.com \\
\hline http://www.doctorsaab.com & http://www.meditimes.com & http://www.wholehealthnow.com \\
\hline http://www.indiadiets.com & $\mathrm{http}: / /$ www.doctornet.com & http://www.yogasite.com \\
\hline http://www.healthcarehouse.com & $\mathrm{http}: / /$ www.ayurjobs.net & hww.Ayurvedandall.com \\
\hline
\end{tabular}

Table 3: Some of the useful websites for doctors-academicians-students

\begin{tabular}{|c|c|}
\hline Topic & Name of the Website \\
\hline Aryavaidyan, Arya Vaidya Sala & http://www.aryavaidyasala.com \\
\hline AYU, Institute For Post Graduate Teaching and Research In Ayurveda, \\
Gujarat Ayurvedic University, Jamnagar & http://www.biomedcentral.com \\
\hline BMC Complementary and Alternative Medicine & http://chp.sagepub.com \\
\hline Journal of Evidence-Based Complementary and Alternative Medicine & http://www.hindawi.com/journals/ecam \\
\hline Evidence-Based Complementary and Alternative Medicine & http://ijam.co.in \\
\hline International Journal of Ayurveda and Research & http://www.jaim.in \\
\hline International Journal of Ayurvedic Medicine & http://www.translational-medicine.com \\
\hline Journal of Ayurveda and Integrative Medicine & $\mathrm{http}: / / \mathrm{www}$. ccras.nic.in/publication/Periodicals \\
\hline Journal of Translational Medicine &
\end{tabular}

\section{CONCLUSION}

Ayurved is the most suitable system of medicine in which Information Technology can be applied. The adoption of ICT in Ayurved will enhance the interactions between Ayurved and Modern Medicine.

In this age to meet the healthcare demands of the world community, the interaction between Ayurvedic medicine and Allopathic medicine is essential. The acquisition of knowledge has therefore been the thrust area throughout the world. The economy of present times depends no longer on visible resources and capital goods but on invisible knowledge and information. Therefore, poor nations as well as poor individuals can create wealth through active contacts and use of knowledge and information.

So the need for modernization of Ayurved with the application of ICT is essential to meet the challenges of future healthcare needs of a cyber society. It is a new area where the application of ICT is more evident with regards to the modern Allopathic medicine for the smooth interactions between them, application of ICT in Ayurved is quite essential.

\section{REFERENCES}

1. Briggs JS, Early GH. Internet Developments and their significance for healthcare. Med Inform Internet Med 1999; 24 (3): 149-64. http://dx.doi.org/10.1080/146392399298357 PMid:10654809
2. Kumar K, Singh SP. From information society to knowledge society". Journal of Library and Information Science, 2000;25(2):104-111.

3. Nair Hemachandran. Application of information technology in the treatment and preparation of medicine in Ayurveda with special reference to Kerala. Ph. D Thesis. Dept. of Land IS, University of Calicut. 2003

4. Srinivasan $\mathrm{K}$ et al. Ayurveda and information technology: A preventive and curative approach to healthcare. Sajosps. 2004;4 (2):141-144

5. Thomas, Hilary. Clinical networks for doctors and managers. British Journal of Medicine. 2003;326: 655 http://dx.doi.org/10.1136/bmj.326.7390.655/a PMid:12649250 PMCid: 1125550

6. Beginner's guide to the Internet, Ed Aggarwal, MD, TFY Technical publications, New Delhi.

7. Internetworldstats.com, Miniwatts Marketing Group, c 2001-2013, Page updated on Jan 17, 2013. Available from: http://www.internetworldstats.com/.

8. Shajahan MA. Computer and Ayurveda. Apta. 1998;5 (1): 5-17

9. Kapur Suman. The Internet- Its Role in Medicine and Healthcare, Journal Indian Academy of Clinical Medicine. 2001;2(3)

10. Gorman PN. Information needs of physicians. Journal of the American Society for Information Science. 1995;46: 729-736. http://dx.doi.org/10.1002/(SICI)1097-

4571(199512)46:10<729::AID-ASI3>3.0.CO;2-2

Cite this article as:

Sushant Sud, Khyati S. Sud. Ayur informatics: Need of the hour. Int. J. Res. Ayurveda Pharm. 2013; 4(2):288-290 